\title{
From Pythagoras to Archimedes
}

\section{No Pitagora līdz Arhimēdam}

\author{
Aleksandrs Kovancovs ${ }^{1}$, Inta Volodko ${ }^{2}$ \\ ${ }^{1-2}$ Rīgas Tehniskā universitāte, Latvija
}

\begin{abstract}
Kopsavilkums - Matemātikas vēsturē minēti daudzi slaveni vārdi, par kuriem var arī daudz stāstît. Šoreiz būs runa par dažiem izciliem sengrieḳu matemātiķiem: Talesu, Pitagoru un Arhimēdu. Milētas Talesu var uzskatīt par mūsdienu matemātikas tēvu. Viṇa galvenais nopelns matemātikā bija ideja par matemātisko pierādījumu. Mūsdienu matemātika daudz aizguvusi arī no Pitagora. Pitagora vadībā matemātika kḷuva par zinātni tādā nozīmēe, kā to saprotam šodien, t. i., matemātika sāka darboties ar abstraktiem skaitliem un gèemetriskām figūrām. Pitagorieši nostiprināja matemātiskā pierādījuma ideju, pētīja sakarības starp skaitḷiem un nonāca pie iracionālo skaitlıu jēdziena, bez kā mūsdienu matemātika nav iedomājama, kā arī lika pamatus regulāro daudzskaldṇu teorijai. Ģeniāls senās pasaules matemātikis ir Sirakūzu Arhimēds. Viṇš atklāja sviras likumu, izgudroja bloku sistēmu, kā arī skrūves lielu smagumu pacelšanai. Arhimēds bija ne tikai dižens matemātikis, bet arī izcilākais senās pasaules tehniķis, kura vadībā salīdzinoši neliels l̦aužu pulks ilgā laika posmā spēja pretoties daudziem tūkstošiem bruṇotu vīru.
\end{abstract} Taless.

Atslēgas vārdi - Arhimēds, matemātikas vēsture, Pitagors,

\section{IEVADS}

Par Senās Grieķijas matemātiku var runāt bezgalīgi ilgi. Desmitiem izcilu vārdu, no kuriem katrs jebkuram matemātikas vēstures cien̄itājam skan kā mūzika; desmitiem matemātikas darbu, no kuriem katrs, iespējams, ir ne mazāk aizraujošs kā piedz̄ivojumu romāns vai zinātniski fantastisks stāsts. Nosaucot vienu, grūti atturēties nenosaukt pārējos. Taču, lai izceltu galveno, nāksies kaut ko upurēt.

Jautājot matemātikas vēsturniekiem, kurus trīs Senās Grieḳijas matemātiķus tie uzskata par visizcilākajiem, droši vien pārsvarā atbilde būtu: Eiklīds, Arhimēds, Apollonijs. Tie tiešām ir trīs senās matemātikas valii, un nekāda, pat l̦oti skopa informācija par seno pasauli un tās zinātni nav iespējama, nepieminot šos trīs vārdus.

Eiklīds bija kā fokuss, kurā koncentrējās visa tā laika matemātika, un viņa "Sākums" bija viena no vispopulārākajām grāmatām divarpus tūkstošu gadu garumā, skaitot no tās izdošanas brīža.

Arhimēds - ǵeniāls mehānikis un ǵeometrs, kuru ar pilnām tiesībām var uzskatīt par bezgalīgi mazo lielumu teorijas radītāju, t. i., teorijas, uz kuras balstās visa mūsdienu matemātika.

Apollonijs - konisko šķēlumu teorijas radītājs. Ar tā saucamās ǵeometriskās algebras metodēm, l,oti smagas un loti neērtas algebras (bet neko citu senie grieki diemžēl nezināja), Apollonijs mācēja attīstīt šo teoriju tā, ka mūsdienu augstskolās, izmantojot daudz modernākas metodes, diezgan ilgā laika posmā ir iespējams aplūkot tikai nelielu šīs teorijas daḷu.

Senajā pasaulē matemātika pēc minētajiem trim ǵeometriem turpināja attīstīties, taču vairs ne tik intensīvi kā iepriekš. Tas pārsvarā bija komentētāju laiks, kaut gan arī tad bija sastopami izcili un oriǵināli zinātnieki. Pietiek nosaukt, piemēram, Aleksandrijas Diofantu (3. gs. m. ē.).

2. gadsimtā p. m. è. Grieḳiju pakḷāva Roma. Tas zināmā mērā veicināja zinātnisko sasniegumu attīstības tempu palēnināšanos. Romieši pilnībā neuztvēra abstrakto grieḳu matemātiku un savos pētîjumos galvenokārt aprobežojās tikai ar praktiski lietderīgiem algoritmiem un likumiem. Neskatoties uz to, viṇi netraucēja grieḳiem nodarboties arī ar matemātiskām abstrakcijām.

Mūsu ēras 5. gadsimtā barbaru iebrukumu rezultātā Rietumromas impērija beidza savu pastāvēšanu. Sākās vidējo laiku laikmets.

Taču šoreiz stāsts būs par trim izciliem grieķu matemātiķiem - Talesu, Pitagoru un Arhimēdu.

\section{TALESS}

Par mūsdienu matemātikas tēvu peln̄iti var uzskatīt izcilo sengrieḳu matemātiḳi Milētas Talesu' ${ }^{1}$ (1. att.). Talesu dēvēja

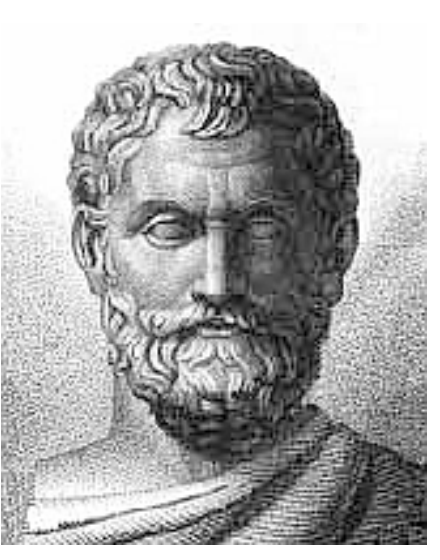

1. att. Taless. par Milētas Talesu, jo viņš bija cēlies no bagātas senās pilsētas Milētas, kas atradās Mazāzijā. Milēta bija grieḳu provinces Jonijas centrs, tāpēc filozofijas skola, kuru nodibināja un vadīja Taless, vēsturē pazīstama kā Jonijas skola.

Galvenais Talesa nopelns matemātikā bija viņa ideja par matemātisko pierādījumu. Mūsdienās šĩ ideja caurstrāvo visu matemātiku.

Stāsta, ka Taless labi zinājis līdzīgu trīsstūru īpašības un pratis ar to palīdzību aprēķināt, piemēram, attālumu līdz kug̣iem jūrā. Un, kas bijis pavisam negaidīti - atrodoties Ēgiptē, viņš izmērījis Heopsa piramīdas augstumu, pat neuzkāpjot tajā.

... Nesaudz̄̄ga Āfrikas saule gāza no debesīm neciešami karstu žilbinošu staru kūli. Viss dzīvais slēpās ēnā. Tālumā, uz

\footnotetext{
${ }^{1}$ https://commons.wikimedia.org/w/index.php?curid=11037570
} 
horizonta, dzeltenos biezu smilšu putekḷu dūmos gulēja bezgalīgs Lībijas tuksnesis. Tuvumā, biezos papirusa brikšnos, kuri slēpa svētās Hapi upes krastus, sastinga krokodilu un hipopotamu kroplīgās maskas [1].

Ëǵipte... Dīvaina, nesaprotama, noslēpumaina, iztēli kaitinoša un neapturami vilinoša zeme. Mīklaina tauta, kas nav līdzīga nevienai citai Oikumenas tautai. Kad un kā tā nokḷuva šajā pasakainajā ielejā? Kā tā izauklēja savu pārsteidzošo, neatkārtojamo civilizāciju? No kurienes tā ṇēma spēku, lai uzceltu šīs gigantiskās, iztēli pārsteidzošās piramīdas, lai no milzīgas klints izgrebtu šo fantastisko, tūkstošus neuzminētu noslēpumu slēpjošo puslauvu, puscilvēku?

Stāvot Izīdas tempḷa augsto kolonnu ēnā, Taless ar alkatīgu ziņkārību vēroja neaptveramā tuksneša žilbinošo dzeltenumu un sfinksu ar tik necilvēcīgi gudru un mūžīgu seju. $\mathrm{Nu}$ jau pagājuši divi gadi, kopš viņš no dzimtās Milētas ieradās šajā zemēe, lai atklātu tās noslēpumus, daudzu gadsimtu kultūras noslēpumus [2].

Ne Sīrija, ne Babilona neizbrīnīja un nepārsteidza viṇu tā, kā pārsteidza š̄ viņa priekšā guḷošā zeme. Tur viss bija vienkārši, šeit - pavisam savādāk. Citi dievi, citi cilvēki, citi uzskati par apkārtējo pasauli. Viṇš uzzināja, ka šī strādīgā tauta ilgus gadsimtus pa kripatai vāca savas apbrīnojamās zināšanas. Š̄is zināšanas tika glabātas tempḷu un valsts krātuvēs. To glabātāji bija priesteri, un smags sods gaidīja tos drosminiekus, kuri kaut domās gribēja pieskarties šiem dārgumiem.

Taless atcerējās, kā vienā no tikpat karstām, saulainām dienām viņš kopāa ar galveno tempḷa priesteri gāja garām Heopsa piramīdai.

- Vai kāds zina, kāds ir š̄s piramīdas augstums? - viṇš jautāja priesterim.

- Nē, mans dēls, - atbildēja priesteris. - Senie papirusi mums to neatklāj, bet mūsdienu zināšanas neḷauj mums pat aptuveni spriest par to.

- Un tomēr to var noteikt precīzi tūlīt pat.

- Dievi ir liecinieki tam, ka tu kḷūdies, mans dēls, - ar neuzticību teica Izīdas priesteris. - Kas tev dod pamatojumu runāt par to ar tādu pārliecību?

- Līdzīgu trīsstūru īpašības, - atbildēja Taless. - Lūk, skaties. Mans augums ir 3 Babilonijas cara elkoni. Bet šeit ir mana ēna. Redzi, galvas ēna stiepjas tieši līdz tam akmenim. Es izmēru attālumu no pēdas vidus līdz akmenim. Tas arī ir 3 Babilonijas cara elkoṇi. Un, lai kādu priekšmetu tu paṇemtu, tagad, tieši šajā dienas laikā, š̄ priekšmeta ēna, ja to novieto vertikāli, sakrīt ar priekšmeta garumu. Pats šāds vertikāli novietots priekšmets un tā ēna veido vienādsānu taisnleṇka trīsstūri. Nu tad zini, ka visi vienādsānu taisnlenk ka trīsstūri ir līdz̄̄gi viens otram. Bet tagad skaties, cik tālu sniedzas piramīdas ēna. Nomērīsim šīs ēnas garumu, sākot no piramīdas pamata, pieskaitīsim tam pusi no pamata garuma un iegūsim piramīdas augstumu. Ievēro to, ka piramīdas pamats ir kvadrāts, bet ēna ir perpendikulāra š̄ kvadrāta malai.

No sava baltā hitona apakšas Taless izvilka tievu auklu, kura ar mezgliem bija sadalīta vienādās daḷās. Attālums starp diviem tuvākajiem mezgliem bija vienāds ar vienu Babilonijas elkoni (mūsdienu mērvienībās 555 mm). Viṇ̌s nekad neškūīās no šîs auklas kopš tiem laikiem, kad pēc Nīlas izkāpšanas no krastiem caurām dienām kopā ar garpedonaptiem klejoja pa vēl nenožuvušo zemi un kopā ar tiem, mācoties no viṇiem un vienlaicīgi mācot vinus, dalīja gabalos ar auglīgām dūņām klātos laukus.

Taless nostiprināja virves galu pie ēnas beigām un novilka to $\operatorname{li}_{\mathrm{d}} \mathrm{z}$ piramīdas tuvākajai pamata malai. Sanāca 50 elkoṇu. Šim skaitlim pieskaitot 207 elkoņus - pusi no jau iepriekš priesteru izmērītā pamata malas garuma, viņš piegāja pie pacietīgi gaidošā priestera.

- 257 elkoṇi. Tieši tik liels ir piramīdas augstums.

Izīdas templa galvenais priesteris bija satriekts. Svešzemniek! Es redzu, ka tu esi gudrs un pieredzējis. Tu redzi to, kas dažreiz mums ir apslēpts. Tu daudz ko esi spriedis un daudz kur iedzilinājies. Taču tavas zināšanas nav smeltas no Ēǵiptes gaišajiem dieviem. No haldiešu kabalistiem un sīriešu burvjiem tu pārn̄ēmi lietu būtības noslēpumu zināšanas. Sargies no šīm zināšanām! Jo daudzas tavas zaimojošās zināšanas nav dieviem tīkamas. Daudz kam no tā, ko tu zini, jābūt apslēptam, mirstīgajiem nepieejamam. Pagriezis Talesam muguru, priesteris ātri devās projām un drīz pazuda zem Izīdas tempḷa augstā portāla.

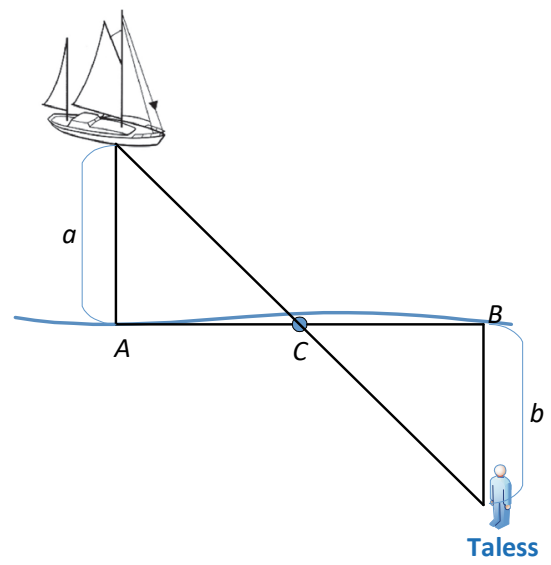

2. att. Shēma attāluma līdz kug̣im noteikšanai.

...Līdzịgu trīsstūru īpašības Taless izmantoja arī, lai noteiktu attālumu līdz kuǵiem jūrā. Šim nolūkam viņš paralēli krastam novilka bāzi (2. att. shēmā tas ir nogrieznis $A B$ ) tā, lai taisne, kas savienoja bāzes galu ar kug̣i, būtu perpendikulāra bāzei (2. att.). Bāzes vidū lika kādu stabinu (punkts $C$ ). Taless gāja pa bāzes perpendikulāri tik ilgi, kamēr viņš, šis stabiņš un kug̣is atradās uz vienas taisnes. Tad viṇa noietais attālums $(b)$ bija vienāds ar attālumu līdz kuǵim $(a)$.

Stāsta, ka dzīvē Taless bijis tāds cilvēks, par kuru saka, ka viņš nav no šīs pasaules. Kādreiz naktī Taless gājis pa lauku un, augstu pacēlis galvu, vērojis zvaigžņoto debesi. Viņš nebija pamanījis priekšā atrodošos bedri un iekritis tajā. Blakus ejošā verdzene nav noturējusies un sarkastiski teikusi: "Kā tu vari zināt, kas notiek debesīs, ja tu nezini, kas atrodas tev zem kājām!?”

Sevišķi slavens Taless kḷva kā saules aptumsuma pareǵotājs. Stāsta, ka tajā laikā notikusi kauja starp divām naidnieku armijām. Karotājus satricinājis ne tik daudz pats aptumsums, kā tas, ka parasts cilvēks var tik precīzi paredzēt šo parādību. Viṇi nekavējoties apturējuši cīṇu un noslēguši mieru. Atdarināšanas cienīgs piemērs! 
...Tagad - par matemātiskā pierādījuma ideju. Kādi iemesli lika Talesam nonākt pie šādas idejas? Atbilde uz šo jautājumu var būt tikai pieņēmums, taču - l̦oti ticams pieņēmums.

Matemātika - tik l,oti atšķirīga no citām zinātnēm, un tajā pašā laikā līdzịga tām. Tāpat kā citās zinātnēs, arī matemātikā darbojas loǵikas likumi. Tas ir saprotams, jo gan zinātnes, gan pašu logiiku ir radījusi apkārtējā realitāte. Loǵikas kā vispārīgas zinātnes par domāšanas likumiem toreiz vēl nebija, tā tikai sāka veidoties, lai pēc trim gadsimtiem pārliecinoši nostiprinātos Aristoteḷa darbos. Taču ar to, ko zināja filozofi 7. gs. p. m. ē., bija pietiekami, lai spriestu tādās kategorijās, kuras mēs tiem piedēvēsim. Tā, piemēram, mēs nosakām, ka A ir lielāks par B un B ir lielāks par C. Tad nav jājautā apkārtējai pasaulei, kāda ir saistība starp A un C, - tad uzreiz varam pateikt, ka A ir lielāks par C. Turklāt nav nekādas nozīmes, vai lielumi A, B, C ir matemātiski vai jebkāda cita veida lielumi. Ne-matemātikā attieksme "lielāks" var būt, piemēram, vecuma attieksme (ja A ir vecāks par B un B ir vecāks par $C$, tad A ir vecāks par C), bet matemātikā šai attieksmei var būt tīri matemātiska nozīme. Piemēram, ja nogrieznis A ir garāks par nogriezni B un B ir garāks par C, tad A ir garāks par C. Taču tādā gadījumā matemātikā no apkārtējās pasaules mēs varam ņemt tikai daḷ no informācijas, bet pārējo daḷu iegūt "galvā" spriedumu un pierādījumu veidā.

Tās patiesības, kuras mēs iegūstam tieši no apkārtējās vides, sauc par aksiomām. Savukārt patiesības, kuras iegūstam ar log̣isku spriedumu palīdzību, sauc par teorēmām. Mēs nezinām, tieši kādas aksiomas noformulēja Taless, tāpat arī nezinām, kā Taless pierādīja savas pirmās teorēmas. Vēlāku autoru darbi liecina, ka Taless it kā esot pierādījis šādas teorēmas:

1) diametrs sadala riṇkii divās kongruentās daḷās;

2) vienā riņk̄ī jebkura horda ir īsāka par diametru;

3) vertikālie leṇkịi ir savstarpēji vienādi;

4) trīsstūri var pilnībā definēt, uzdodot vienu malu un divus tai piegulošos leṇķus.

Mēs nevaram ar pilnu pārliecību apgalvot, ka šīs teorēmas tiešām pierādījis Taless. Dažos gadījumos Talesam piedēvē teorēmas, balstoties tikai uz "veselo saprātu". Piemēram, Taless nevarētu noteikt attālumu līdz kug̣im jūrā, ja nezinātu 4. punktā formulēto patiesību. Šādas "piedēvēšanas" tika izdarītas iepriekš un tiek izdarītas arī tagad.

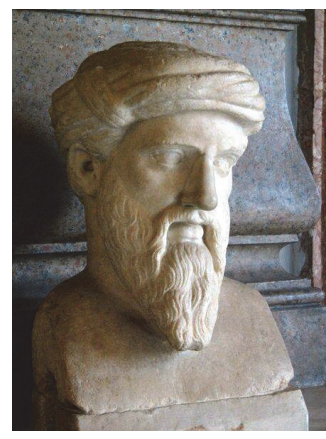

3. att. Pitagora krūšutēls, Kapitolija muzejs, Romā.

\section{PITAGORS}

Talesa jaunākais laikabiedrs bija Pitagors no Samosa salas, kuru tāpēc arī sauca par Samosas Pitagoru (3. att.).

Mums nav pilnas pārliecības par to, kas bija īstais Pitagors, ja viņš patiešām bija.

Ja viņš patiešām bija...? Vai par to ir šaubas? Ir. Iespējams, ka senajos laikos eksistēja liela matemātikas skola, kuras sekotāji visus savus atklājumus piedēvēja vienai personai, kuru nosauca par Pitagoru.
Arī mūsdienās zināmi tādi gadījumi. Piemēram, franču matemātiķu grupa izdod savus darbus, un kā to autoru norāda Nikolasu Burbaki (Nicolas Bourbaki). Patiesībā tāds Burbaki neeksistē, taču vina darbi, kā redzams, ir.

Kāpēc tad mēs šaubāmies tieši par Pitagora eksistenci, bet ticam citu seno laiku zinātnieku eksistencei? Lieta tāda, ka par Pitagoru stāsta tik daudz dažādu leǵendu, ka ticēt tām ir vienkārši neiespējami. Tāpēc pati par sevi rodas doma - vai eksistēja cilvēks, par kuru to stāsta. Spriediet paši! Stāsta, ka reiz Pitagors piegājis pie upes. Tajā pašā mirklī upe izgājusi no krastiem (pēc citas versijas - upe pacēlusies visā tās garumā) un saukusi: "Slava Pitagoram!” Piekrītiet, ir iemesls šaubām [3].

Neskatoties uz iepriekš teikto, mēs stāstīsim par Pitagoru, pieṇemot, ka tāds cilvēks tiešām eksistēja un tiešām paveica to, ko viņam pieraksta. Pieminēsim, ka neviens Pitagora darbs līdz mūsdienām tā arī nav nonācis. Taču tas, ko par Pitagora darbību stāsta vēlākie autori, ir avots, no kura daudz ko aizguvusi mūsdienu matemātika.

Tagad iztēlē pārcelsimies uz senās Grieķijas pilsētu Metapontu 6. gs. līdz mūsu ērai. ...Naksnīgās Metapontas miegaino klusumu pārtrauca griezīgs kliedziens. Bija dzirdama smaga ķermeņa kritiena skaņa, skrejošu kāju dipon,a, un tad viss apklusa. Kad uz notikuma vietu atsteidzās naktssardze, tā lāpas plīvojošā gaismā ieraudzīja uz zemes izstiepušos sirmgalvi. Viṇa krūtīs rēgojās rēta, iecirsta ar abpusēji griez̄̄gu ieroci. Pie sirmgalvja pietupies sēdēja gadus divpadsmit vecs zēns un gauži raudāja.

- Kas ir šis cilvēks? - jautāja sardzes kapteinis.

- Tas ir Pitagors, - atbildēja puisēns un pacēla pret debesīm rādītājpirkstu.

- Kas ir Pitagors? Mūsu pilsētas kopienā nav cilvēka ar tādu vārdu.

- Mēs bijām spiesti slēpties. Sākumā Samosā, tad Krotonā. Mans kungs izgāja ārā tikai naktīs. Bet ienaidnieki tik un tā uzgāja mūsu pēdas. Viņi ilgi mūs izsekoja un panāca šeit, Metapontā.

- Cik vinu bija?

- Es nepaspēju saskaitīt. Viṇi atsvieda mani sāṇus un uzbruka manam kungam.

Sardzes kapteinis noslīga uz celiem un pielika ausi pie sirmgalvja krūtīm.

- Protams, - viņš teica, - sirds vairs nesitas. Pastāsti mums par savu kungu.

...L̨oti iespējams, tieši tā savu dz̄̄vi beidza ievērojamais grieķu prātnieks. Tajā laikā viņam bija 80 gadu, bet aiz muguras vētraina dzīve, pilna ar briesmām un piedzīvojumiem.

Ko tad varēja pastāstīt kalps par savu kungu?

Eksistē interesanta Pitagora biogrāfija. Tiek uzskatīts, ka Pitagors dzimis uz ziedošās un bagātās Samosas salas 6. gs. sākumā p. m. ē. Viņš piedzima bagātā aristokrātu ǵimenē. Līdzīgi kā daudzi vina laikabiedri, Pitagors jaunībā daudz cel̦ojis, galvenokārt pa Tuvo Austrumu valstīm (Feniķija, Sīrija, Bābele). Stāsta, ka viņš esot pabijis arī Éǵiptē, kur viṇu esot paṇēmusi gūstā Persijas cara Kambiza armija, kura toreiz mēǵināja iekarot Ēǵipti.

Var noprast, ka tajā laikā Pitagors jau bija ieguvis izcila zinātnieka un brīnumdara slavu. Tāpēc, kad cars Kambizs 
uzzināja, kas tieši nonācis pie vina gūstā, viṇš atvainojies zinātniekam un ar godu viņu atlaidis.

Atgriezies dzimtajā Samosā, Pitagors sapulcināja ap sevi jauniešu grupu, kura sāka nodarboties ar zinātniskiem pētījumiem filozofijā un matemātikā. Pitagora skolai pēc austrumu puszinātnisko, pusreliǵisko skolu parauga bija slepens raksturs. Lai iekḷūtu skolā, bija jāiztur smagi pārbaudījumi. Minēsim dažus faktus, kas to apliecina.

Lai pieradinātu savus audzēknus turēt noslēpumā visu, kas atklāts skolā, Pitagors licis tiem klusēt piecus gadus. Tikai pēc tam varēja sevi uzskatīt par Pitagora skolēnu. Tos, kuri neizturēja šo pārbaudījumu, sauca par akusmatiḳiem. Viṇiem bija tiesības tikai klausīties savu dievišḳo (kā viṇu sauca) skolotāju, taču viṇi to neredzēja. Šim nolūkam telpa, kurā Pitagors mācīja, ar aizslietni tika sadalīta divās dalās. Vienā sēdēja Pitagora skolēni - vini gan redzēja, gan dzirdēja savu skolotāju; otrajā bija akusmatiḳi - vini tikai dzirdēja Pitagoru, taču neredzēja to. Stāsta, ka starp Pitagora audzēkṇiem bijušas arī divas sievietes. Tāpēc acīmredzot, runājot par sievietēm matemātiķēm, jāsāk tieši ar tām pitagorietēm, kuru vārdus diemžēl vēsture nav saglabājusi.

Kaut kas notika, kas tieši - mēs nezinām, taču Pitagora skola tika iznīcināta. Ļoti iespējams, ka tās pārstāvji neaprobežojās tikai ar zinātniskiem pētījumiem, bet mēǵināja iejaukties arī valsts politiskajā dzīvē. Tas nepatika tirānam Polikratam, kurš tajā laikā valdīja valstī. Pitagoriešus sāka vajāt. Tas piespieda viṇus bēgt no salas un meklēt patvērumu citur. Lielākā daļa pitagoriešu aizbēga uz tā saucamo Lielo Griekiju - tā toreiz sauca Griekijas austrumu piekrasti un mūsdienu Itālijas dienvidus. Pats Pitagors nonāca pilsētā Krotonā, pēc tam viņš bija spiests pārcelties uz Tarentu un tad uz Metapontu, kur viņš mira 80 vai pat 90 gadu vecumā (it kā nogalināts kādā naktī vienā no ielu sadursmēm).

Ko tad izdarīja pitagorieši?

Svarīgākais ir tas, ka pitagoriešiem matemātika kḷuva par zinātni tādā nozīmēe, kā mēs to saprotam šodien. Matemātikas pamatideja: tā darbojas ar abstraktiem skaițiem un geometriskām figūrām, nevis ar skaițiem, kas nosaka, piemēram, konkrētu škidruma trauku tilpumu un konkrētu zemesgabalu laukumu, un ne ar figūrām, kuras ir kādas istabas durvis, upurtrauki templī utt. Pitagoriešiem matemātika kḷuva par abstraktu zinātni atšksirībā no tā, kā tas bija éğiptiešiem un bābeliešiem, pie kuriem Pitagors mācījās un kuru sasniegumus viņš pacēla kvalitatîvi jaunā līmenī.

Jāpievērš uzmanība tam, ka formai, kuru pitagorieši piešķ̄ira saviem matemātikas rezultātiem, bija pusreliǵisks, pusmistisks raksturs - tie bija sava veida mesli laikmetam, taču cauri tam visam vijās matemātikas zinātniskais raksturs, kurš ar laiku noveda pie tādu brīnišķ̄īgu matemātisku zinātņu atklājuma kā skaitḷu teorija, regulāru daudzskaldṇu teorija, proporciju teorija u. c.

Lūk, tas bija tā.

Tāpat kā mūsdienās, pitagorieši visus skaițus sadalīja pāra un nepāra skaiț̣os. Bet ar to viṇi neaprobežojās. Nepāra skaitḷus tie sauca par labajiem skaitḷiem, pāra - par ḷaunajiem. Vieninieku uzskatīja par labā un l̦aunā sākuma nesēju. Kāpēc? Tāpēc, ka vieninieka pieskaitīšana labo skaitli padara par launo, bet ļauno - par labo.
Skaitli, kuru var izteikt kā divu citu skaitļu reizinājumu, sauca par plakanu vai taisnstūrveida. Skaitli, kuru var izteikt kā triju skaitļu reizinājumu, sauca par kermenisku. Atbilstoši parādījās termini "kvadrāts" un "kubs". Atgādināsim, ka matemātika par pirmskaitli sauc skaitli, kas dalās tikai pats ar sevi un ar vieninieku. Jebkuru skaitli var izteikt kā pirmskaițu reizinājumu. Šo pirmskaitḷu reizinājumi veido tā saucamos skaița dalītājus. Piemēram, skaitlis 12 sadalās pirmskaiţ̦os 2, 2, 3. Tà dalītāji, neskaitot vieninieku, ir 2, 3, 4 un 6. Skaitļus sauca par draudzīgiem, ja viena skaița dalītāju summa sakrīt ar otro skaitli. Tādi, piemēram, ir skaiții 220 un 284.

Atzīmēsim, ka par skaiț̣a dalītāju nav jāṇem pats skaitlis, taču jāṇem vieninieks:

$$
284=1+2+4+5+10+11+20+22+44+55+110
$$

(no labās puses ir skaitḷa 220 dalītāji),

$$
220=1+2+4+71+142
$$

(no labās puses ir skaiț̣a 284 dalītāji).

Par piln̄̄giem skaițiem sauca skaițus, kuri ir vienādi ar savu dalītāju summu (no dalītāju saraksta izslēdzot pašu skaitli). Tādi, piemēram, ir skaitḷi:

$$
6=1+2+3, \quad 28=1+2+4+7+14 .
$$

Piezīmēsim, ka mūsdienās tiek veikti pētījumi par pilnīgo skaitḷu sadalījumu. Tiek pētīts, cik pilnīgo skaițu atrodas starp skaitḷiem $\pi$ un $2 \pi$. Piebildīsim, ka atrast atbildes uz šādiem

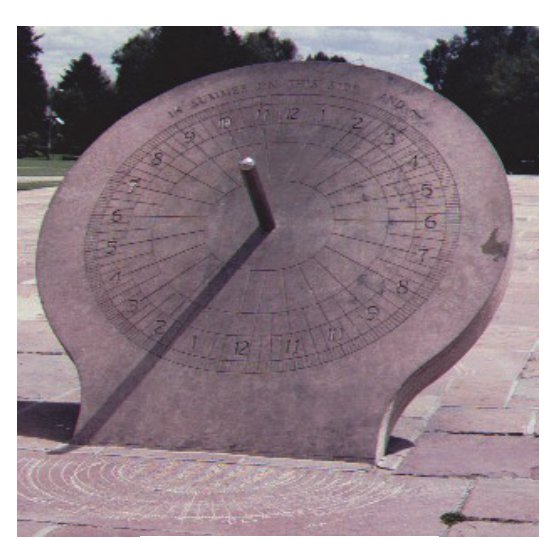

4. att. Gnomons. jautājumiem ir loti grūti un šādu problēmu risinājumus augsti vērtē matemātikas biedrības.

Senajā Griekijāà laiku noteica, izmantojot tā saucamo "gnomonu"2 (4. att.). Tā sauca ierīci, kura nedaudz līdzinājās slāvu burtam $\Gamma$ To novietoja atklātā laukumā tā, ka tās ēna krita uz iezīmētu apli ar iedaḷām. Blakus šīm iedaļām rakstīja skaițus. Tās arī bija stundas un minūtes. Saulaino dienu bija daudz, tāpēc gnomons parasti strādāja bez traucējumiem.

Pitagorieši par gnomoniem sauca nepāra skaitļus; viṇi noteica arī, ka nepāra skaițu (gnomonu) summa ir skaiţ̦a kvadrāts. Tiešām, pēc kārtas pierakstītu nepāra skaitḷu summa ir vienāda ar šo skaitḷu skaita kvadrātu:

$$
\begin{gathered}
1=1^{2}, \quad 1+3=4=2^{2}, \quad 1+3+5=9=3^{2}, \\
1+3+5+7=16=4^{2},
\end{gathered}
$$

\footnotetext{
2 http://www.ancientpages.com/2016/11/03/gnomon-ancient-time-measuringinstrument-used-by-babylonians-egyptians-and-chinese/
} 


$$
1+3+5+7+9=25=5^{2} \text { utt. }
$$

Lielu vērību pitagorieši pievērsa arī skaitliem, kurus tie sauca par trīsstūrveida skaitḷiem: $1,3,6,10,15,21, \ldots$. Nosaukums "trīsstūrveida skaitlıi” radies no tā, ka, iztēlojoties vieninieku kā bumbiņu un saliekot attiecīgo skaitu vieninieku (bumbiņu) trīsstūros, kā to dara biljarda spēles sākumā, vajadz̄̄gs tieši tāds skaits bumbiṇu kā iepriekš minētie skaitḷi. $(5 . \text { att. })^{3}$.

Atbilstoši, ja pēc kārtas saskaita trīsstūrveida skaitļus, iegūst skaitlıu, kurus pitagorieši sauca par piramīdveida skaitḷiem. Tiešām, ja ņem trīsstūri no, piemēram, 10 bumbin̄ām, tad tam virsū var uzlikt trīsstūri no 6 bumbin̄ām, savukārt tam virsū - trīsstūri no 3 bumbiņām, un visbeidzot pašā augšā - 1 bumbiṇu. Iznāk piramīda.

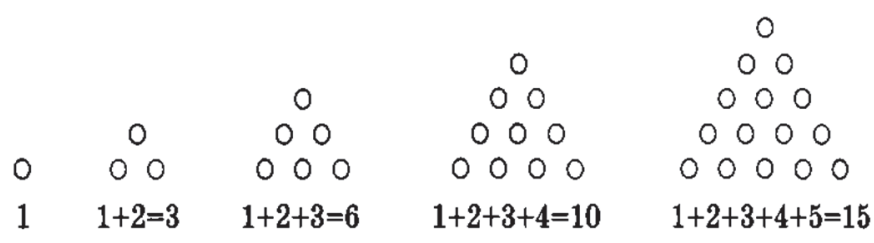

5. att. Trīsstūrveida skaitḷu attēlojums.

Ārpus pitagoriešu uzmanības nepalika arī tā saucamo proporciju īpašības. Tika aplūkotas triju veidu proporcijas: aritmētiskā, ǵeometriskā un harmoniskā. Uzskatīja, ka trīs skaitḷi $a, b, c$ veido nepārtrauktu aritmētisko proporciju, ja $a-b=b-c$. Šajā gadījumā $b=a+c / 2$ sauc par skaitḷu $a$ un $c$ vidējo aritmētisko. Uzskatīja, ka trīs skaitļi $a, b, c$ veido nepārtrauktu ǵeometrisko proporciju, ja $a: b=b: c$. Tādā gadījumā $b=\sqrt{a c}$ sauc par skaițu $a$ un $c$ vidējo ǵeometrisko. Šìs proporcijas bija zināmas jau pirms pitagoriešiem. Kas attiecas uz trešā veida proporciju, tā saucamo harmonisko proporciju, to atklāja un pamatīgi izpētīja tieši pitagorieši. Šī proporcija ir: trīs skaiț̣i $a, b, c$ veido harmonisko proporciju, ja $a: c=(a-b):(b-c)$. Šajā gadījumā $b$ sauc par skaitḷu $a$ un $c$ vidējo harmonisko un nosaka pēc formulas $b=\frac{2 a c}{a+c}$.

Harmoniskās proporcijas atklājums ir l̦oti nozīmīgs pitagoriešu atklājums, jo šādas proporcijas dz̄ivēe sastopamas ik uz soḷa un tām ir tikpat liela loma kā tā saucamajam "zelta šḳēlumam” $\frac{a}{b}=\frac{b}{a+b}$ vai harmonisko punktu četriniekam.

Piemērs. Aplūkosim labi zināmo izliektas lēcas formulu:

$$
\frac{1}{r_{1}}+\frac{1}{r_{2}}=\frac{1}{f} \rightarrow \frac{1}{r_{1}}-\frac{1}{2 f}=\frac{1}{2 f}-\frac{1}{r_{2}}
$$

Šajā formulā skaiții $r_{1}, 2 f, r_{2}$ veido nepārtrauktu harmonisko proporciju. Šeit $r_{1}$ ir attālums no priekšmeta līdz lēcai, $r_{2}-$ attālums no lēcas līdz attēlam, $2 f$-divkāršais fokusa attālums (skat. 6. att.) $)^{4}$. Savukārt harmonisko punktu četriniekiem ir

\footnotetext{
3 http://900igr.net/fotografii/algebra/Kombinatorika-i-teorija-verojatnosti/008Treugolnye-chisla.html

${ }^{4}$ http://macibas.e-skola.lv/mod/book/tool/print/index.php?id=203
}

liela nozīme tādā zinātnē kā projektējošā ǵeometrija. Tagad to māca daudzās augstākajās mācību iestādēs - universitātēs, pedagoǵiskajās augstskolās, inženierbūvju augstskolās utt.

Harmoniskās proporcijas mēdz saukt arī par muzikālajām, jo tās ir cieši saistītas ar muzikālajiem akordiem. Pitagors nejauši atklāja, ka gadījumā, kad divu vienādi nostieptu stīgu garumu attiecība ir vienāda ar veselu skaitlu attiecību, turklāt tieši ar pirmo naturālo skaitḷu attiecību, tad tādas stīgas, skanot vienlaicīgi, rada akordu. Tāda pati sakarība veidojas, ja vienlaicīgi skan trīs stīgas. Piemēram, oktāva atbilst attiecībai $2: 1$, kvinta $-3: 2($ do + sol $)$, kvarta $-4: 3($ do + fa), lielā terce 5:4 (do + mi), mazā terce $-6: 5$ (do + mi bemols).

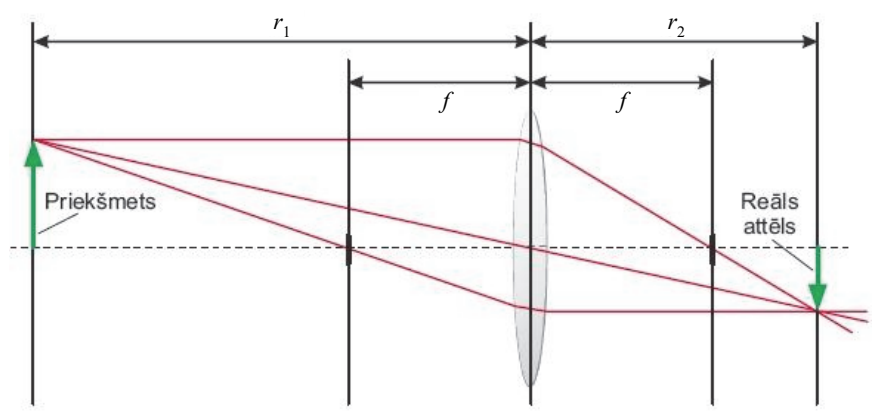

6. att. Lēcas darbības princips.

N̦emsim, piemēram, triju skaņu akordu: do + mi bemols + sol. Ja skaņas "do" svārstību skaitu sekundes laikā uzskata par vieninieku, tad skaņas "mi bemols" svārstību skaits ir 6:5, bet skaņas "sol” svārstību skaits - 3:2 (pamattonis + mazā terce + kvinta).

Viegli saprast, ka skaitlis 6:5 (akorda vidējā skaṇa) ir ārējo skaņu 1 (pamattonis) un 3:2 (kvinta) vidējais harmoniskais:

$$
6: 5=\frac{2 \cdot 1 \cdot \frac{3}{2}}{1+\frac{3}{2}}
$$

Skaņa "mi” maz atšķiras no skaņas "mi bemols", tāpēc arī akords "do + mi + sol" cilvēka ausij ir viegli uztverams un ir viens no pamatakordiem do mažora gammā. Tiesa gan, uz klavierēm norādīto skaņu frekvenču attiecība nav tik tīra un precīza, kā mēs to nosaucām, jo klavieru noskaņošana ir sarežǵīta, taču cilvēka dzirde to praktiski neuztver. Tīros akordus var iegūt, piemēram, uz vijoles, kur ir iespēja iegūt skaņas ar jebkuru svārstību frekvenci (protams, noteiktās robežās).

Pitagorieši pievērsa lielu uzmanību dažāda veida sakarībām starp skaitliiem un apkārtējās realitātes parādībām. Piemēram, viņi uzskatīja, ka Saule kopā ar citām planētām riņķo pa sfērām apkārt kādai centrālai ugunij, turklāt sfēru rādiusi attiecas viens pret otru tāpat kā veselie skaiț̣i. Riņķojot planētas it kā izdod skaņas, no kurām veidojas akordi, un rodas tāda kā vispasaules sfēru harmonija.

Tajā pašā laikā pitagorieši uzskatīja, ka jebkuri lielumi (garumi, laukumi, tilpumi u. c.) attiecas viens pret otru kā veselie skaitḷi. Tāpēc liels bija viņu izbrīns, kad tie nejauši atklāja, ka kvadrāta malas garuma attiecība pret tā diagonāli nav veselo skaitļu attiecība. Tagad viegli pierādīt, ka gadījumā, kad kvadrāta malas garums ir, piemēram, 1, tā 
diagonāle ir vienāda ar $\sqrt{2}$, kas ir iracionāls skaitlis. Pitagorieši nenonāca līdz iracionālu skaitḷu jēdzienam. Tādi skaitļi vienkārši nevar būt! Kā tad izkḷūt no šāda nepatīkama stāvokḷa? Atbilde ir: "Paturēt to noslēpumā." Un glabāt noslēpumus tie mācēja - lai kḷūtu par pitagoriešiem, viṇi taču klusēja piecus gadus! Sanāk, ka eksistē ne tikai veselo, bet arī citu skaitḷu attiecības. Taču - slēp vai neslēp, ilgi šo atklājumu nenoslēpsi. Pagāja kāds laiks, un iracionāla skaitḷa noslēpumu uzzināja cilvēki, kuri nebija Pitagora skolnieki. Runā, ka šo noslēpumu izpḷāpājis viens no Pitagora skolniekiem Metapontas Gipass. Atradās taču nešḳīstenis, kurš pārkāpa noslêpuma zvērestu! Ko ar vinu darīt? Pitagorieši lūdza palīdzību dieviem. Tajā laikā, kad Gipasa kuği, pilni ar dārgām precēm (visi pitagorieši bija turīgi ḷaudis), atgriezās dzimtajā ostā, jūras dievs Poseidons uzsūtīja briesmīgu vētru, kas noslīcināja kuğus un kopā ar tiem - arī to īpašnieku.

Ko tad pitagorieši izdarīja ǵeometrijas jomā? Acīmredzot pirmais, kas nāk prātā, ir slavenā teorēma, ko sauc par Pitagora teorēmu. Teorēmu gan sauc Pitagora vārdā, taču ir zināms, ka teorēmā noformulêto faktu bābelieši zinājuši jau tūkstoš gadu pirms Pitagora. Bābelē prata viegli rēkināt uzdevumus, kuros bija jāatrod taisnstūra diagonāle. Iespējams, ka Pitagors pierādīja šo teorēmu, taču mēs nezinām, kurš no vairākiem teorēmas pierādījumiem ir viṇa darbs. Sakarā ar teorēmas pierādīšanu Pitagors it kā esot upurējis dieviem vienlaicīgi tikuši nogalināti simts vērši (upuri sauca par hekatombu).

Eksistē daudzi Pitagora teorēmas pierādījumi (divi

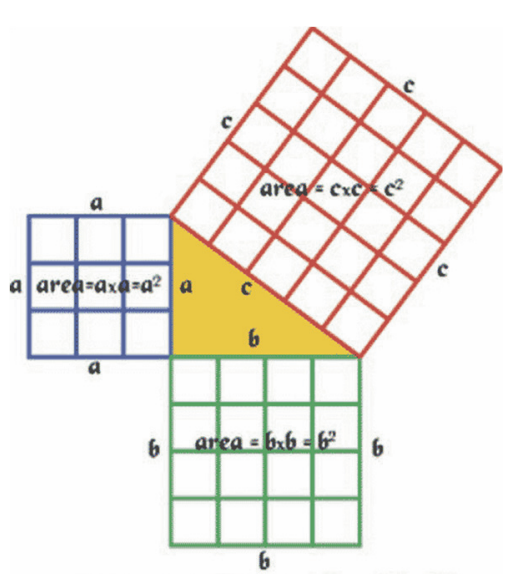

Pythagoream Theorem: $c^{2}=a^{2}+b^{2}$
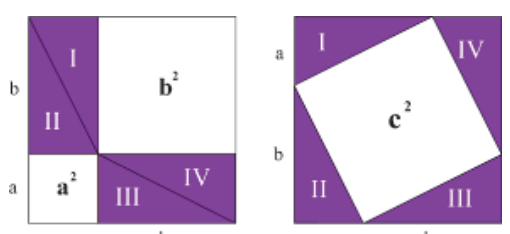

7. att. Ilustrācijas Pitagora teorēmas pierādījumam. populārākie redzami 7. att. $)^{5}$. Dažādu tautu pārstāvji dažādos laikos atraduši atšḳirīgus pierādījumus. Viens no tiem ir aprakstīts Eiklīda darbā "Sākums". Vairākus pierādījumus viduslaikos atraduši indieši, turklāt pierādījumiem doti romantiski nosaukumi. Piemēram, viens no pierādījumiem saucas "līgavas krēsls". Šeit gan uz katetēm uzbūvētie kvadrāti, gan uz hipotenūzas būvētais kvadrāts izkrāsoti tā, ka tie tiešām atgādina krāšņu līgavu krēslā.

Ir vēl viens ievērojams atklājums, ko pitagorieši veica geometrijā. Viṇi atklāja regulārus daudzskaldnuus. Mēs zinām, ka Eiklīda telpā eksistē tikai pieci tādi daudzskaldṇi. Tie ir: tetraedrs (četrskaldnis), kubs (sešskaldnis), oktaedrs (astoņskaldnis), dodekaedrs

\footnotetext{
${ }^{5}$ http://www.myastrologybook.com/Pythagoras-proof-PythagoreanTheorem.htm, http://faculty.smcm.edu/sgoldstine/pythagoras.html
}

(divpadsmitskaldnis) un ikosaedrs (divdesmitskaldnis) (8. att. $)^{6}$. Pirmie trīs tika atklāti jau agrāk, pēdējie divi ir pašu pitagoriešu atklājums.

Senajos laikos (arī mūsdienās) regulārajiem daudzskaldṇiem piešḳīa lielu uzmanību. Pitagorieši, piemēram, dodekaedra atklājumu uzskatīija par vienu no saviem svarīgākajiem atklājumiem. Uzskatīja, ka katram regulāram daudzskaldnim atbilst kāda no stihijām, no kurām sastāv pasaule: kubs - zemes stihija; tetraedrs - uguns stihija; ikosaedrs - gaisa stihija; oktaedrs - ūdens stihija. Kas attiecas uz dodekaedru, tad to uzskatīja par tik svarīgu figūru, ka tā bija stihiju stihija. Vēlāk latīnu valodā to nosauca par kvintesenci. Šì vārda tiešais tulkojums ir "piektā stihija".

Uzskata, ka visas senās matemātikas centrālais darbs Eiklīda "Sākums" - tika uzrakstîts tieši tādēl, lai pamatotu regulāru daudzskaldṇu konstruēšanas teoriju.

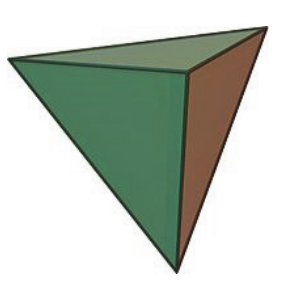

tetraedrs

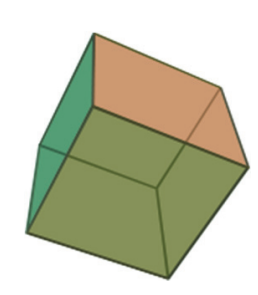

kubs

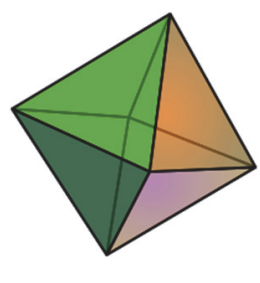

oktaedrs
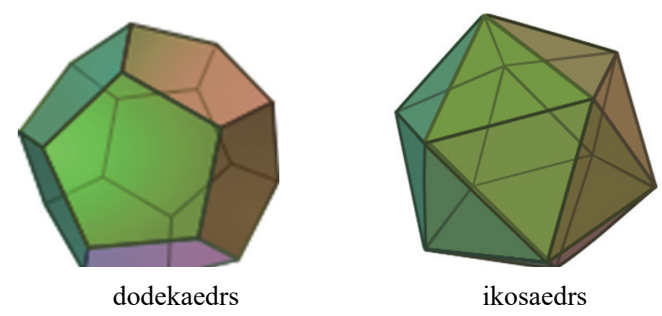

8. att. Regulārie daudzskaldṇi.

Tātad pitagoriešus interesēja pietiekami daudzveidīgi jautājumi. Raugoties no mūsdienu viedokḷa, viņi nepierādīja nevienu sarežğîtu teorēmu, tāpat kā neuzbūvēja nekādu īpašu teoriju. Vēl jo vairāk, daudz kas no viṇu atklājumiem bija naivs, viņu pētījumi savijās ar reliǵioziem aizspriedumiem utt. Taču nedrīkst aizmirst, ka viņi bija pirmie vai gandrīz pirmie. Viṇi nostiprināja matemātiskā pierādījuma ideju (daži pat uzskata, ka tieši Pitagors bija šis idejas pamatlicējs). Viṇi nonāca pie iracionālu skaiț̣u jēdziena, bez kuriem mūsdienu matemātika nav iedomājama. Viņi lika pamatus regulāro daudzskaldṇu teorijai (nākamajos gadsimtos pitagoriešu pētījumiem pievienojās arī citi). Bet kādi neregulārie daudzskaldṇi eksistē? Cik tādu ir? Un kas notiek četru, piecu utt. dimensiju telpās? Utt., u. t. jpr.

Stāstu par Pitagoru pabeigsim ar viņa filozofijas pamatu:

"Visus cilvēkus var iedalīit trijās grupās, tāpat kā visus cilvēkus, kas apmeklē Olimpiskās spēles, var iedalīt trijās grupās. Zemākā sastāv no tiem, kas nāk pirkt un pārdot. Nākamie ir tie, kas sacenšas. Taču visaugstākie ir tie, kas nāk skatīties. Cilvēkus attiecīgi var iedalīt tajos, kam svarīga manta, tajos, kam svarīgs gods, un tajos, kam svarīga gudrība.

\footnotetext{
${ }^{6}$ https://commons.wikimedia.org/wiki/File:Platonic_solids.jpg
} 
Tātad visaugstākā apskaidrība ir zinātne bez interesēm un cilvēks, kas sevi tai ziedo, patiesais filozofs, kas sevi veiksmīgi atbrīvojis no "dzimšanas apḷa".

\section{ARHIMĒDS}

Iepazīsimies ar vēl vienu slavenu senās pasaules ǵeometru Sirakūzu Arhimēdu (9. att.) ${ }^{7}$.

Ja Eiklīda persona zūd viņa galvenā darba "Sākums" fonā, tad Arhimēda persona saskatāma daudz labāk.

Senai Romai bija smagi un nogurdinoši kari ar pilsētvalsti Kartāgu, kas atradās Vidusjūras Āfrikas piekrastē. Pavisam tādu karu bija trīs. Vēsturē tie paz̄istami ar nosaukumu "pūniešu kari” (romieši Kartāgas iedzīvotājus sauca par pūniešiem).

Otrā Pūniešu kara (218.-201. g. p. m. ē.) beigās tika sakauts slavenais kartāgiešu karavadonis Hanibals, kas bija romiešu

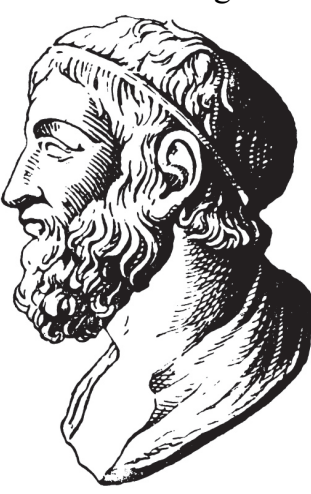

9. att. Arhimēds. bieds.

Šajā laikā grieḳu pilsēta Sirakūzas, kas atradās Sicīlijas dienvidu krastā, bija Kartāgas sabiedrotā, tāpēc tā regulāri tika pakḷauta romiešu flotes uzbrukumiem. Romiešu armiju vadīja Marcels.

Ilgu laiku pilsētu uzskatīja par neieņemamu. Sirakūzas iedzīvotāji to varonīgi aizstāvēja, un nebūt ne maznozīmīgu lomu tajā spēlēja izcilais zinātnieks - matemātiķis, mehāniķis, filozofs - Arhimēds.

Viņš piedzima 287. gadā p. m. ē., bija astronoma Feidija dēls, no sava tēva ieguva lielisku izglītību, daudz celıja. Būdams Ėǵiptē, satuvinājās ar tā laika pazīstamiem matemātiķiem - Erastostenu, Kononu, Dosifeju. Savu izglīīibu turpināja Eiklīda Aleksandrijas skolā.

Visu savu dz̄ivi Arhimēds veltīja zinātnei un savas dzimtās pilsētas aizstāvēšanai. Būdams pilsētas goda loceklis, viņš bija draugos ar caru Hieronu un tā dēlu Helonu. 212. gadā p. m. è. laikā, kad Marcels iekaroja Sirakūzas - Arhimēds gāja bojā.

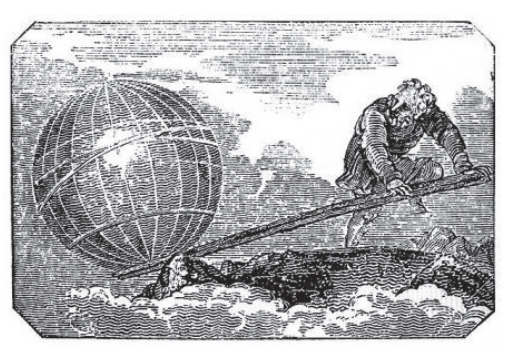

10. att. Sviras likuma darbība.
Viňš atklāja sviras likumu, izgudroja bloku sistēmu, kā arī skrūves un poliplastus lielu smagumu pacelšanai, kas deva iespēju bez lielām pūlēm pacelt uz augšu aiz "deguna" (10. att. $)^{8}$ ienaidnieku kuǵus, nokratīt nost to klāja tur esošos un noslīcināt tos. Viņš būvēja kara metējmašīnas, kuras spēja lielos attālumos izsviest milzīgus akmenus. Šīs mašīnas apšāva ienaidnieku galeras un slīcināja tās. Vēsture stāsta, ka Arhimēds no karavīru zelta vairogiem

\footnotetext{
${ }^{7}$ https://www.math.nyu.edu/ crorres/Archimedes/Pictures/ ArchimedesPictures.html

${ }^{8}$ The engraving is from Mechanic's Magazine (cover of bound Volume II, Knight \& Lacey, London, 1824)
}

uzkonstruējis parabolisku spoguli, ar tā palīdzību savācis Saules starus vienā kūlī un sadedzinājis ienaidnieka floti.

Arhimēds uzbūvēja planetāriju, kuru vēlāk redzēja un aprakstīja romiešu orators Cicerons. Arī prāta uzdevumus lielākoties izgudrojis Arhimēds.

Arhimēds bija ne tikai viens no pirmajiem matemātiķiem, bet arī slavens senās pasaules tehniķis.

Viņš atklāja ne tikai sviras likumu, bet arī pamatoja teoriju par šķidrumu līdzsvaru (11. att.).

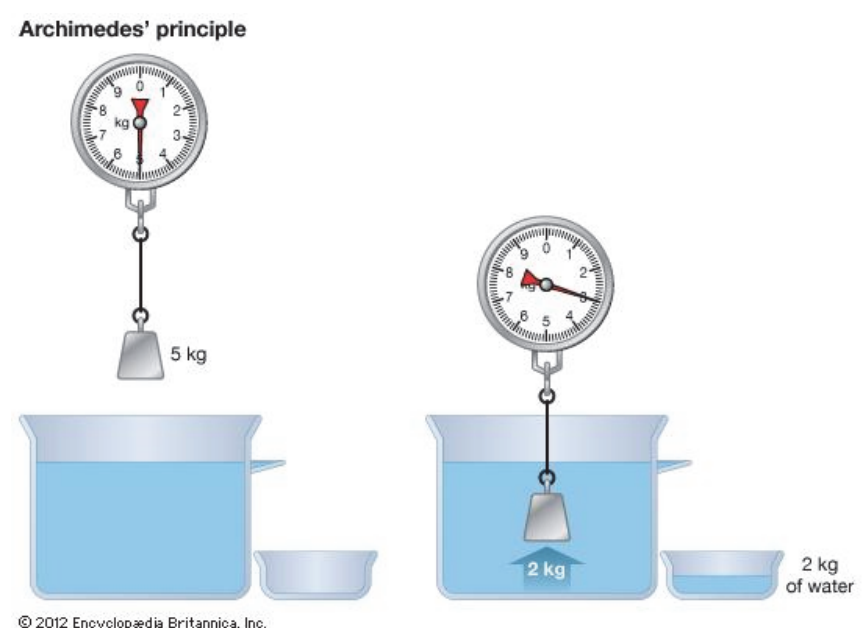

11. att. Ilustrācija teorijai par škiidrumu līdzsvaru.

Pateicoties Arhimēdam, helēnistiskā pasaule gatavojās pārejai no matemātikas uz fiziku un no fizikas uz tehniku. Taču romiešu valdības gudrības trūkums kavēja šì nodoma īstenošanu. Arhimēds guva izcilus panākumus kara tehnikas jomā, un tas radīja romiešos paniku. Viṇa katapultas varēja regulēt šāviena attālumu. Ar to palīdzību bija iespējams uzbrukt ienaidnieka flotei, neizejot ārpus pilsētas sienām. Stāsta, ka sakarā ar savu sviru teoriju Arhimēds esot teicis: "Dodiet man atbalsta punktu, un es apgāzīšu zemeslodi." Līdz mūsdienām saglabājušies šādi Arhimēda darbi (daži gan tikai dal̦ēji): par statiku, par parabolas kvadratūru, par paraboliska segmenta smaguma centru, "Efodika" jeb mācība par metodi,

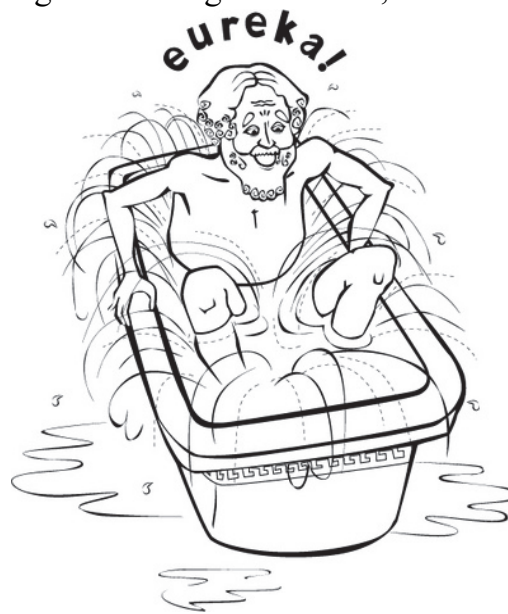

12. att. Likuma par k̦ermeṇa iegremdēšanu škidrumā atklāšana. par lodi un cilindru, par spirāli, par rotācijas ķermeņiem, par peldošiem priekšmetiem, par rinķa līnijas mērīšanu, par smilšu graudu skaitīšanu.

Leǵenda vēsta par kuriozu epizodi no Arhimēda dzives, kad viņš atklāja likumu par ķermeņa iegremdēšanu škidrumā (12. att. $)^{9}$

Saskaņā ar šo leǵendu, atklājot savu slaveno likumu,

\footnotetext{
${ }^{9}$ https://couldhavebeenacoconuttree.files.wordpress.com/2011/05/ archimedes_bath.jpg
} 
zinātnieks esot aizrāvies tik lielā mērā, ka uztraukumā izlēcis no vannas, kurā mazgājies, un, nemaz neņemot vērā savu nepievilcīgo ārieni, ar kliedzienu "Eurika!" cauri visai pilsētai meties pie cara Hierona, lai pavēstītu tam par savu atklājumu.

Savas dzimtās pilsētas aizstāvēšanā, iespējams, Arhimēdam arī bijusi visaktīvākā loma. Tikai pateicoties vina ǵenialitātei, pilsēta tik ilgi varēja pretoties romiešu karavīiem.

Kādā triecienuzbrukumā, kurš tomēr beidzās ar pilsētas ieņemšanu, Arhimēdu nogalināja. Romieši ilgu laiku nevarēja noticēt, ka viens cilvēks tik ilgā laika posmā varējis pretoties daudzu tūkstošu apbrunotu vīru apvienotiem spēkiem.

Lūk, ko par Arhimēda bojāeju stāsta izcilais grieķu vēsturnieks Plūtarhs, kurš dz̄ivoja 400 gadus pēc Arhimēda [4]:

"Visvairāk Marcelu apbēdināja Arhimēda nāve. Triecienuzbrukuma laikā Arhimēeds, iegrimis domās, sēdēja pie kādas ğeometriskās figūras, kuru viņš uzmanīgi aplūkoja. Viņš bija tik l,oti aizrāvies, ka pat nepamanīja, ka romieši ieñēma pilsētu. Piepeši vina priekšā parādījās zaldāts un pieprasīja, lai Arhimēds dodas vinam līdzi pie Marcela. Taču Arhimēds piekrita to darīt tikai pēc tam, kad būs atrisinājis uzdevumu un pabeidzis pierādījumu. Sadusmojies zaldāts izrāva zobenu un caurdūra ar to Arhimēdu".

Sekojot Eidoksam un Eiklīdam (12. grāmata), Arhimēds atklāja telpisku ķermeņu tilpumu un smaguma centru aprēḳināšanas veidus, kas, iespējams, ir vina lielākais sasniegums. Tas savukārt vēlāk N̦ūtonam (1642.-1727. g.) un Leibnicam (1646.-1716. g.) deva iespēju radīt diferenciālrēḳinu un integrālrēḳinu teoriju. Turklāt jāṇem vērā, ka Arhimēds katru integrāli aprēḳināja atseviškị, bet N̦ūtonam un Leibnicam bija zināma teorēma par sakarību starp diferencēšanu un integrēšanu.

\section{LITERATŪRAS SARAKSTS}

[1] D. Armand, Kak izmerili Zemlju, (in Russian). L., Detgiz, 1941

[2] I. Ja. Depman, Rozpovidi pro matematiku, (in Ukrainian). K., Radjans'ka shkola, 1957.

[3] N. I. Kovantsov, Matematika i romantika, (in Russian). K. Vishha shkola, 1980.

[4] L. V. Kovantsova and A. N. Kovantsov, Zanimatel'naja istorija matematiki, (in Russian). K., DIJa, 2000.

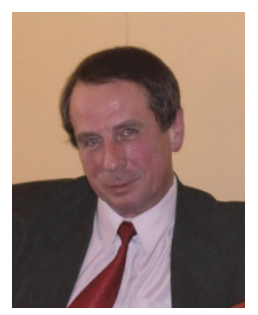

Aleksandrs Kovancovs was born in Kazakhstan. He received the Diploma in Mathematics from the Kiev State University in 1971, and the Doctoral Degree in Mathematics in 1992. Since 2000, he is an Assistant Professor at Riga Technical University, Department of Engineering Mathematics, Faculty of Computer Science and Information Technology.

His research interests include math history, Geometry of the decision of systems of ordinary differential equations and Elementary Geometry application for design of different functions.

E-mail: akovancova@baltinet.lv

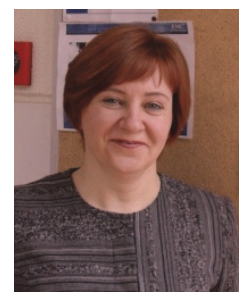

Inta Volodko was born in Kraslava, Latvia. She received the Diploma in Mathematics from the University of Latvia in 1988, and the Doctoral Degree in Mathematics in 1995. Since 1988, she works for Riga Technical University.

She is now a Professor at Riga Technical University, Department of Engineering Mathematics, Faculty of Computer Science and Information Technology and a Head of Department. Her research interests include issues of mathematical pedagogy, math history and mathematical modelling of non-destructive testing. E-mail: inta.volodko@rtu.lv

From Pythagoras to Archimedes

Aleksandrs Kovancovs ${ }^{1}$, Inta Volodko ${ }^{2}$

${ }^{1,2}$ Riga Technical University, Latvia

In the history of mathematics, there are a lot of famous names, and much can be said about them. This paper is dedicated to some outstanding Ancient Greek mathematicians: Thales of Miletus, Pythagoras and Archimedes. Thales of Miletus can be considered the father of today's mathematics. His main achievement in mathematics was his idea about mathematical proof. Today, mathematics is not imaginable without proofs.

Today's mathematics has undoubtedly taken a lot from Pythagoras of Samos Island. There are many interesting facts in the biography of Pythagoras. Pythagoras gathered around himself a group of young people, who started doing scientific research in philosophy and mathematics. This group was later named the School of Pythagoras. Under Pythagoras leadership, mathematics became the science in the meaning we understand it today, that is, mathematics started working with abstract numbers and geometrical figures. Here are some of Pythagorean achievements: they strengthened the idea of mathematical proof; they researched relationships between numbers and came to the concept of irrational numbers, without which today's mathematics is impossible; established the base for the regular polygon theory.

Archimedes of Syracuse is another great mathematician of the ancient world. Archimedes devoted all his life to science and protecting his home town from attacks of the Roman fleet. Thanks to Archimedes, Syracuse was considered an inaccessible city for a long time. Archimedes discovered the lever law, invented the block system, screws and polyplastics to lift great weigh. He built war throwing machines that were able to throw huge stones to a great distance. Archimedes was not only a great mathematician, but also the greatest technician of the ancient world, under the leadership of whom a small group of people in a long period of time could resist the power of thousands of armed men.

Keywords - Archimedes, Mathematical history, Pythagoras, Thales. 